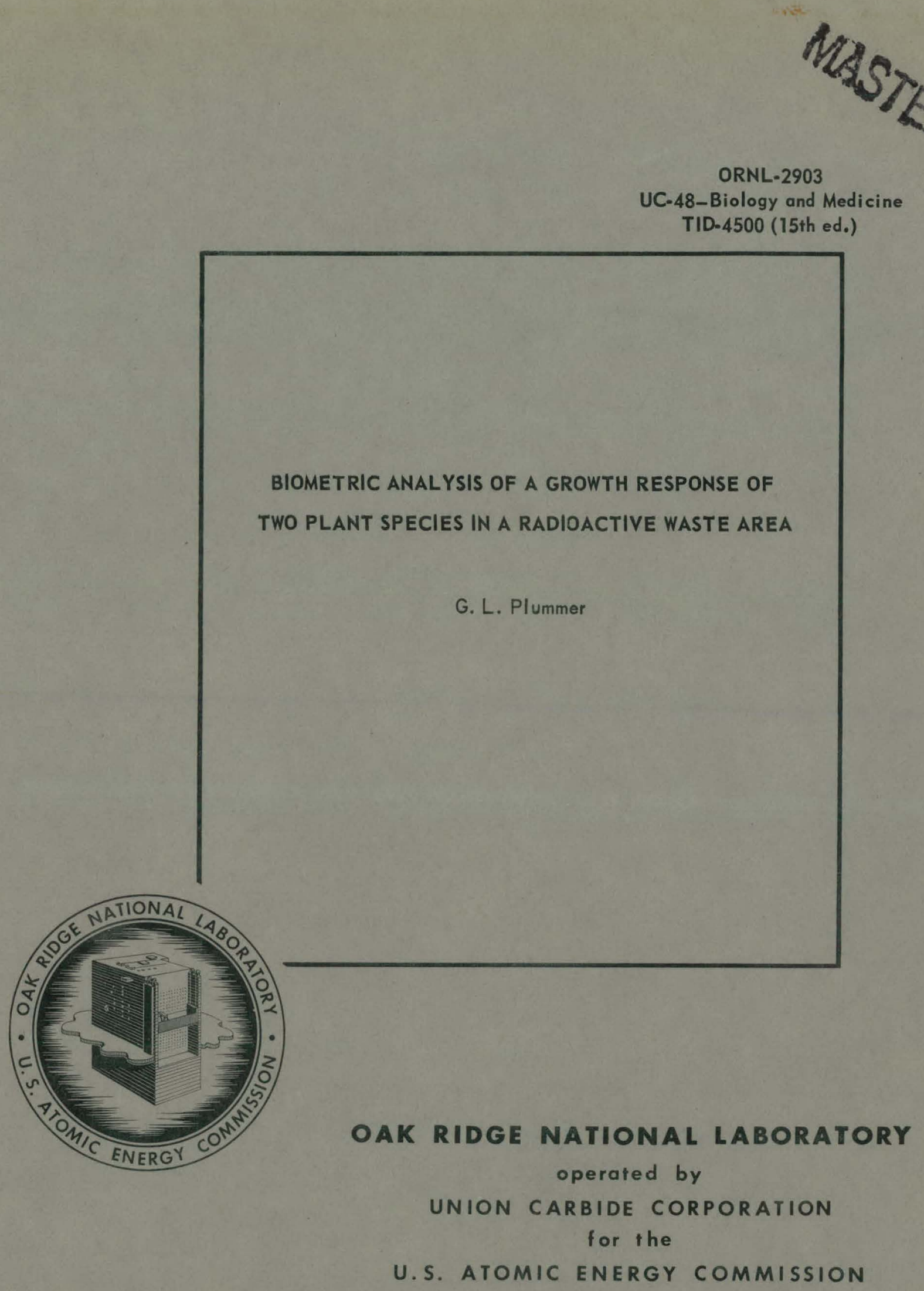




\section{DISCLAIMER}

This report was prepared as an account of work sponsored by an agency of the United States Government. Neither the United States Government nor any agency Thereof, nor any of their employees, makes any warranty, express or implied, or assumes any legal liability or responsibility for the accuracy, completeness, or usefulness of any information, apparatus, product, or process disclosed, or represents that its use would not infringe privately owned rights. Reference herein to any specific commercial product, process, or service by trade name, trademark, manufacturer, or otherwise does not necessarily constitute or imply its endorsement, recommendation, or favoring by the United States Government or any agency thereof. The views and opinions of authors expressed herein do not necessarily state or reflect those of the United States Government or any agency thereof. 


\section{DISCLAIMER}

Portions of this document may be illegible in electronic image products. Images are produced from the best available original document. 


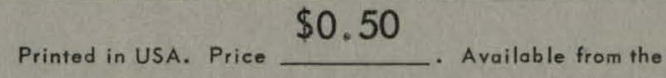

Office of Technical Services

Department of Commerce

Washington 25, D.C.

\section{LEGAL NOTICE}

This report was prepared as an account of Government sponsored work. Neither the United States, nor the Cammission, nor any person acting on behalf of the Commission:

A. Makes any warranty or representation, expressed or implied, with respect to the accuracy, completeness, or usefulness of the information contained in this report, or that the use of any information, apparatus, method, or process disclosed in this report may not infringe privately owned rights; or

B. Assumes any liabilities with respect to the use of, or for damages resulting from the use of any information, apparatus, method, or process disclosed in this report.

As used in the above, "person acting on behalf of the Commission" includes ony employee or contractor of the Commission, or employee of such contractor, to the extent that such employee or contractor of the Commission, or employee of such contractor prepares, disseminates, or provides access to, any information pursuant to his employment or contract with the Commission, or his employment with such contractor. 
Contract No. W-7405-eng-26

HEALTH PHYSICS DIVISION

BIOMETRIC ANALYSIS OF A GROWTH RESPONSE OF

TWO PLANT SPECIES IN A RADIOACTIVE WASTE AREA

G. L. Plummer

DATE ISSUED

\section{APR 251960}

OAK RIDGE NATIONAL LABORATORY

Oak Ridge, Tennessee

operated by

UNION CARBIDE CORPORATION

U. S. ATOMIC ENERGY COMMISSION 


\section{THIS PAGE}

\section{WAS INTENTIONALLY LEFT BLANK}




\section{CONTENTS}

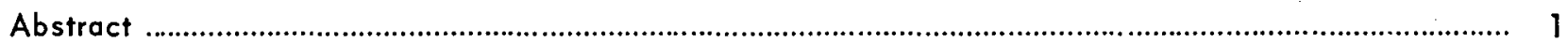

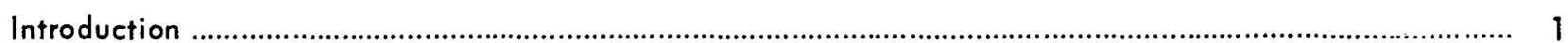

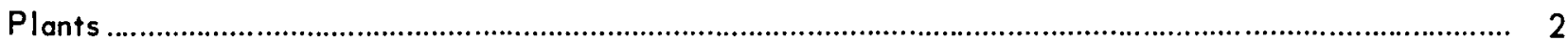

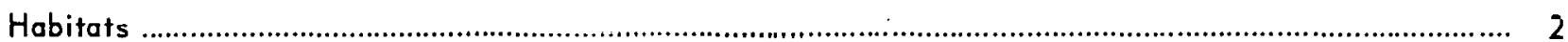

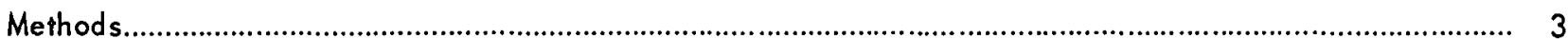

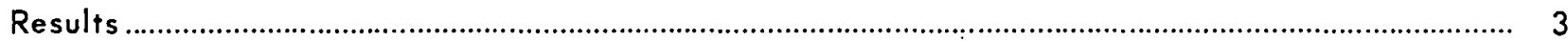

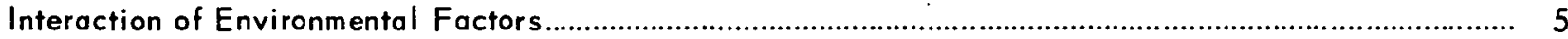

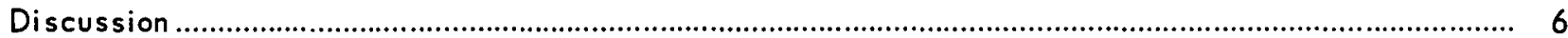

Summary

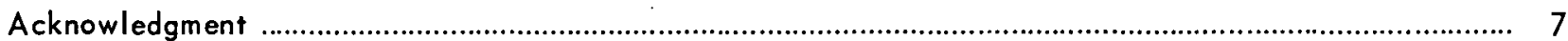




\title{
BIOMETRIC ANALYSIS OF A GROWTH RESPONSE OF TWO PLANT SPECIES IN A RADIOACTIVE WASTE AREA'
}

\author{
G. L. Plummer ${ }^{2}$ \\ ABSTRACT \\ Lengths of pistillate inflorescences of sedges (Carex spp.) growing in the contaminated \\ soils of White Oak Lake bed were measured in relation to radiation fields. Carex Frankii Kunth \\ and Carex vulpinoidea Michx. populations were sampled from areas with air dose rates of 0 , \\ 10,20 , and $40 \mathrm{mr} / \mathrm{hr}$. Analyses of variance showed that mean lengths of inflorescences of $C$. \\ vulpinoidea were similar to each other in these areas but that those of C. rrankii were signiti- \\ cantly different: $0 \mathrm{mr} / \mathrm{hr}, 93.8 \mathrm{~mm} ; 10 \mathrm{mr} / \mathrm{hr}, 96.4 \mathrm{~mm} ; 20 \mathrm{mr} / \mathrm{hr}, 122.0 \mathrm{~mm}$; and $40 \mathrm{mr} / \mathrm{hr}, 110.7 \mathrm{~mm}$. \\ However, the sites differ in such foctors as soil maisture, fertility, and alkalinity, so that these \\ differences in the length of inflorescence may not be accounted for primarily by the exposure \\ dose rate of the radiation field.
}

\section{INTRODUCTION}

Since ionizing radiation in certain environments is increasing both from weapons fallout and from radioactive waste disposal, there is interest in the possible effects of these materials on the native flora and fauna. This investigation employed biometric techniques to analyze a growth habit of two sedges, Carex Frankii Kunth and Carex vulpinoidea Michx., for evidence of manifestation of rodiation effects. The plants inhabit the White Oak Lake bed, a radioactive waste disposal area in which the dose rate of radiation is many times that ever expected to occur in an ordinary environment.

Both morphogenetic and physiological growth responses are known to occur in various plant species exposed to ionizing radiation. Recently, Mewissen et al. ${ }^{3}$ pointed out that chronic irradiation enhanced certain growth characteristics of seed-grown Andropogon filifolius, a-grass, from uraniferous soils. On the other hand, plants growing in the areas of fallout from the 1954 Bikini hydrogen bomb test exhibit "... some correlation between intensity of observed symptoms

\footnotetext{
'This work is part of an investigation conducted under the Research Participation Program of the Oak Ridge Institute of Nuclear Studies in the Ecology Section, Health Physics Division.

${ }^{2}$ Research participant from the University of Georgia Department of Botany.

${ }^{3}$ D. J. Mawissen, J. Dramblon, and Z. M. Bacq, Nature 183, 1449 (1959).
}

and intensity of recorded fallout." 4 The responses by plants to ionizing radiation have been widely reported.5 Many of the responses are undesirable, but some are quite favorable.

Any effect of ionizing radiation upon plants is of interest to the plant biologist. Gross morphoand physiogenetic aberrations have been observed at dose rates from $15 \mathrm{r} /$ day upward. 6 Chromosomal mutations occur with even less radiation. Ionizing radiation is capable of inducing chemical changes both in the soil and within the plant. In general, plants depend upon mineral nutrients that are organized into rather select arrangements. If the suitable arrangement is disturbed by ionizing radiation, a new physiological makeup cuuld produce very subtle responses in growth habits without affecting the obvious morphology of the plant. Therefore, competition, survival, and even evolutionary trends in plant community structure are subject to change.

The objective of this investigation was to determine whether these sedges produced a measurable response which could be attributed to the dose rate from ionizing radiation in their habitat.

\footnotetext{
${ }^{4} F$. R. Fosberg, Nature 183, 1448 (1959).

${ }^{5}$ A. H. Sparrow, J. P. Binnington, and V. Pond, Bibliography on the Effects of Ionizing Radiations on Plants, 1896-1955, BNL-504 (July 1958).

${ }^{6}$ A. H. Sparrow and W. R. Singleton, Am. Naturalist $87,29-48$ (1953).
} 


\section{PLANTS}

The sedges in this study are pioneers in the revegetation of lowland habitats. Carex Frankii Kunth and $C$. vulpinoidea Michx. are nembers of a genus consisting of more than 1100 species, some of which are abundant in arctic, alpine, and temperate habitats. They are perennials which propagate from seed and from underground stems. Many species of the genus hybridize readily. The flowering parts, namely, inflorescences (Fig. 1),

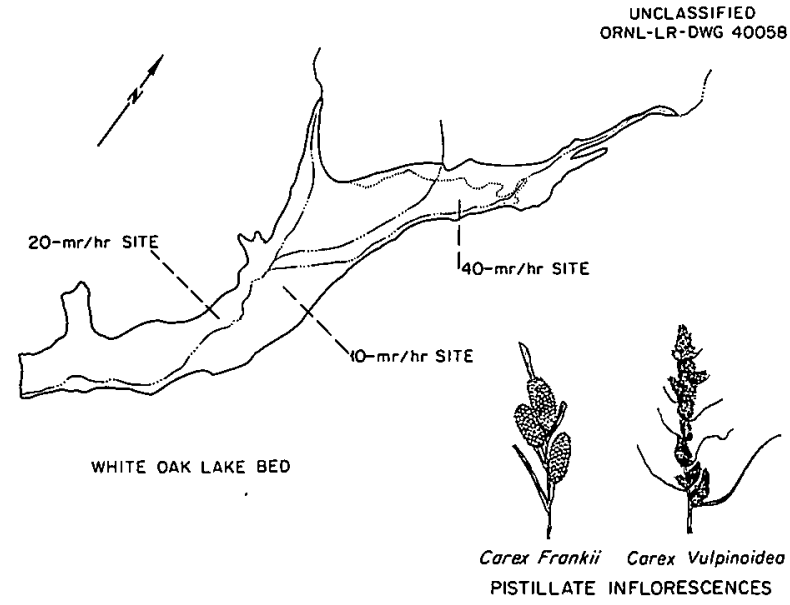

Fig. 1. Sedges, Dose Rates, and Collecting Areas of White Oak Lake Bed, Summer 1959.

consist of the pollen-producing structures situated above the seed-producing (pistillate) spikes. Carex vulpinoidea has a distinct form, $C$. vulpinoidea forma segregata, distinguished by an elongated and obviously segregated group of spikes along the lower portion of the flowering stalk. The ratio of occurrence in the field appeared to be about one forma segregata to eight of the typical species. Intermediates and grada. tions occur suggesting hybridization.

Plants respond to a large number of environmental factors, including soil fertility, soil water, etc., and perhaps to ionizing radiation where present. For the purposes of this study it was assumed that the size of the pistillate spikes is related to the quality of site on which the plants grow, since this is common to nearly all plants. In other words, as the combination of environmental factors becomes more favorable, plants grow larger and reproduce more abundantly.

\section{HABITATS}

White Oak Lake bed is a unique ecological system of about 48 acres. The radiation field above the soil surface has been described, ${ }^{7}$ and additional observations show a range in dose rate from approximately 10 to $300 \mathrm{mr} / \mathrm{hr}$. Records are kept on the characteristics of the vegetation and soil, 8,9 and translocation studies of important radionuclides have been made. 10

Communities of Carex and Juncus (the rushes) occur in several large patches where the over-all dose rate at $1 \mathrm{~m}$ above the bed surface is relatively uniform with intensities of approximately 10,20, and $40 \mathrm{mr} / \mathrm{hr}$ (Fig. 1). The wettest places occur at the lower end of the lake bed, which is covered with backwater in the early spring; the dose rate is $20 \mathrm{mr} / \mathrm{hr}$, and the soil is very alkaline, $\mathrm{pH} 8$ to 8.4 . The driest radiation site, $40 \mathrm{mr} / \mathrm{hr}$, coincides with the highest elevation, where the soil is slightly alkaline, $\mathrm{pH} 7$ to 7.4. The 10$\mathrm{mr} / \mathrm{hr}$ site may be considered as intermediate in respect to all the above factors.

The size and luxuriant growth of the plants suggest that effluents from industrial and domestic wastes brought large quantities of nitrates into the old lake. During the past four growing seasons, following drainage of the lake, the vegetation has flourished in obvious response to this ofttimes limiting mineral nutrient.

In areas outside the lake bed, where there are no such radiation fields present, the soils are generally acid, $\mathrm{pH} 5$ to 6.5 . The small size of the plants indicates that the supply of nitrates is limited. The sedges consort with the rushes in communities that are not dissimilar, floristically, to those on the radiation sites. Five areas were found as suitable "control" sites. Wet, dry, and intermediate soil moisture sites occur, all of which provided adequate plant materials to harvest for comparison.

\footnotetext{
${ }^{7}$ P. K. Lee and S. I. Auerbach, Determination and Evaluation of the Radiation Field Above Wbite Oak Lake Bed, ORNL-2755 (1959).

${ }^{8} \mathrm{H}$. R. DeSelm, Plant Taxa Occurring on the White Oak Lake Bed Grid - 1956, 1957, 1958, Mimeographed list, University of Tennessee, Department of Botany (1959).

${ }^{9} \mathrm{R}$. M. Anderson et al., H.P Ann. Prog. Rep. July 31, 1957. ORNL-2384, p i0; S. I. Auerbach et al., H-P Ann. Prog. Rep. July 31, 1958, ORNL-2590, p 27.

${ }^{10}$ E. R. Grahom, Soil Sci. 86, 91-97 (1958).
} 


\section{METHODS}

Several hundred mature culms of both species were collected in mid-June from different stations on four kinds of sites: no radiation, 10, 20, and $40 \mathrm{mr} / \mathrm{hr}$. Each collection site was sampled at not less than two stations. Each station within a site covered an area of about $50 \mathrm{~m}^{2}$. Ten stations on the lake bed and ten stations in the control sites were sampled.

An effort was made to avoid duplicate sampling within individual clumps as well as within groups having a common parent (clones). Also, both species were collected within the same square meter as frequently as possible. Twenty-five plants were picked at random from the mass of plants gathered at each radiation site and from the control areas as a whole. These plants were separated for measurement as representatives of the particular site. An additional group of 25 plants was measured on three of the four kinds of sites.

The length of each flowering heod of $C$. vulpinoidea, from the lowest spike to the topmost spike, was measured to the nearest mil. limeter. On the other hand, each pistillate spike of $C$. Frankii was measured individually and the sum of all spikes per culm was used as an index of the aggregate length of the flowering part of the plant. As a result of these slightly different measurements on the floral morphology, the two species may not be strictly comparable with each other; nevertheless, the magnitudes of length in both cases are relative.

\section{RESULTS}

Table 1 presents the basic information obtained from all measurements. The last two columns are intended to be comparable; that is, the column headed "Mean" represents the averages for all the data obtoined from plants growing on the radiation sites, whereas the column headed "Controls" represents the averages of the plants at all the collecting stations without radiation.

The two species appeared to respond differentially to the presence or absence of significant ionizing radiation. The mean length of the spikes of $C$. Frankii was greater for the plants from the lake bed than it was for controls (109.7 vs 93.8), whereas in C. vulpinoidea the samples from the control sites had the longer mean head lengths (67.6 vs 63.2).

These relationships suggest that an analysis of variance within each species might distinguish some significant relationships between length and

Table 1. Measurements Taken from Inflorescences of Two Species of Sedges

\begin{tabular}{|c|c|c|c|c|c|}
\hline & \multicolumn{3}{|c|}{ Rodiation Site } & \multicolumn{2}{|c|}{ Habitots } \\
\hline & $10 \mathrm{mr} / \mathrm{hr}$ & $20 \mathrm{mr} / \mathrm{hr}$ & $40 \mathrm{mr} / \mathrm{hr}$ & Mean* & Controls \\
\hline \multicolumn{6}{|c|}{ C. uulpinoidea } \\
\hline Number of heads measured & 50 & 50 & 25 & 50 & 50 \\
\hline Total length (mm) & 3114 & 2998 & 1686 & 3161 & 3380 \\
\hline Variance (sigma squared) (mm) & 187.7 & 115.7 & 167.0 & 167.4 & 138.5 \\
\hline Mean length of heads $(\mathrm{mm})$ & 62.3 & 60.0 & 67.4 & 63.2 & 67.6 \\
\hline \multicolumn{6}{|c|}{ C. Frankii } \\
\hline Number of spikes measured & 212 & 244 & 113 & 112 & 97 \\
\hline Number of plants measured & 50 & 50 & 25 & 25 & 25 \\
\hline Total length of spikes $(\mathrm{mm})$ & 4821 & 6098 & 2767 & 2742 & 2345 \\
\hline Variance (sigma squared) $(\mathrm{mm})$ & 262.0 & 464.2 & 290.4 & 338.8 & 380.9 \\
\hline Mean length of spikes $(\mathrm{mm})$ & 96.4 & 122.0 & 110.7 & 109.7 & 93.8 \\
\hline
\end{tabular}

* An average derived from meosurements on plants at the three radiation sites. 
dose rate. The data shown in Table 2 have been adjusted to 25 plants measured from each radiation site. The analyses of variance tables are composited by parts in Table 3 . The variance ratio is to be interpreted as the observed $F$ value, and Snedecor's $F$ value, at a given probability level, is shown in the right column.

In tracing the source of the differences in total length shown in Table 1 , the data for $C$. vul. pinoidea on four radiation sites were treated as shown in Table 3. The observed value of $F$ is 2.46 and the probability that the absolute value of $F$ exceeds 2.70 is $5 \%$. Therefore, the length of inflorescences in this species probably does not differ with dose rate, and those plants growing on the lake bed are quite similar to those on the "control" sites.

Table 2. Table of Sums

C. Frankii and C. vulpinoidea - length of inflorescences' on four kinds of sites

\begin{tabular}{|c|c|c|c|c|}
\hline \multirow{2}{*}{$\begin{array}{c}\text { Site } \\
(\mathrm{mr} / \mathrm{hr})\end{array}$} & \multicolumn{2}{|c|}{ C. vulpinoidea } & \multicolumn{2}{|c|}{ C. Frankii } \\
\hline & $\Sigma_{x}$ & $\sum x^{2}$ & $\Sigma_{x}$ & $\sum x^{2}$ \\
\hline 0 & 1690 & 117,715 & 2,345 & 226,985 \\
\hline 10 & 1557 & 101,662 & $2,41.1$ & 238,970 \\
\hline 20 & 1499 & 92,773 & 3,049 & 383,461 \\
\hline 40 & 1686 & 117,880 & 2,767 & 313,511 \\
\hline Total & 6432 & 430,030 & 10,572 & $1,162,927$ \\
\hline
\end{tabular}

In another analysis; not shown here, of $C$. vulpinoidea from the control sites and from the $20-\mathrm{mr} / \mathrm{hr}$ site (which produced the longest and shortest inflorescences respectively) the infloresences. on the control sites were not significantly longer at a probability of $5 \%$ than the ones on the $20 \cdot \mathrm{mr} / \mathrm{hr}$ sites.

When the data for C. Frankii are treated similarly (Table 3), the calculated $F$ value is 12.77 and the probability that the absolute value of $F$ exceeds 3.98 is $1 \%$. The large difference between the values of $F$ indicates that the lengths of the pistillate inflorescences in this species probably differ with site.

The Tukey-Hartley test for comparisons among means is useful to distinguish which sites differ from the others. This test is based upon computing a difference, $D$, which is significant at the $5 \%$ level, then comparing it with the $a(a-1) / 2$ sample differences in the investigation; ${ }^{11} D$ is the product of sample standard error and factor $Q$, which differs for each range of treatment means. Thus,

where

$$
D=\left(s_{\bar{x}}\right)\left(Q_{f, a}\right),
$$

$$
\begin{aligned}
& f=\text { degrees of freedom, } \\
& a=\text { number of treatments compored, }
\end{aligned}
$$

I'G. W. Snedecor, Statistical Methods, 5th ed., lowa State College, Ames, 1956.

Table 3. Analyses of Varlance

C. vulpinoidea and C. Frankii - lengths of inflorescences for $0-, 10-, 20-$, and $40-\mathrm{mr} / \mathrm{hr}$ sites

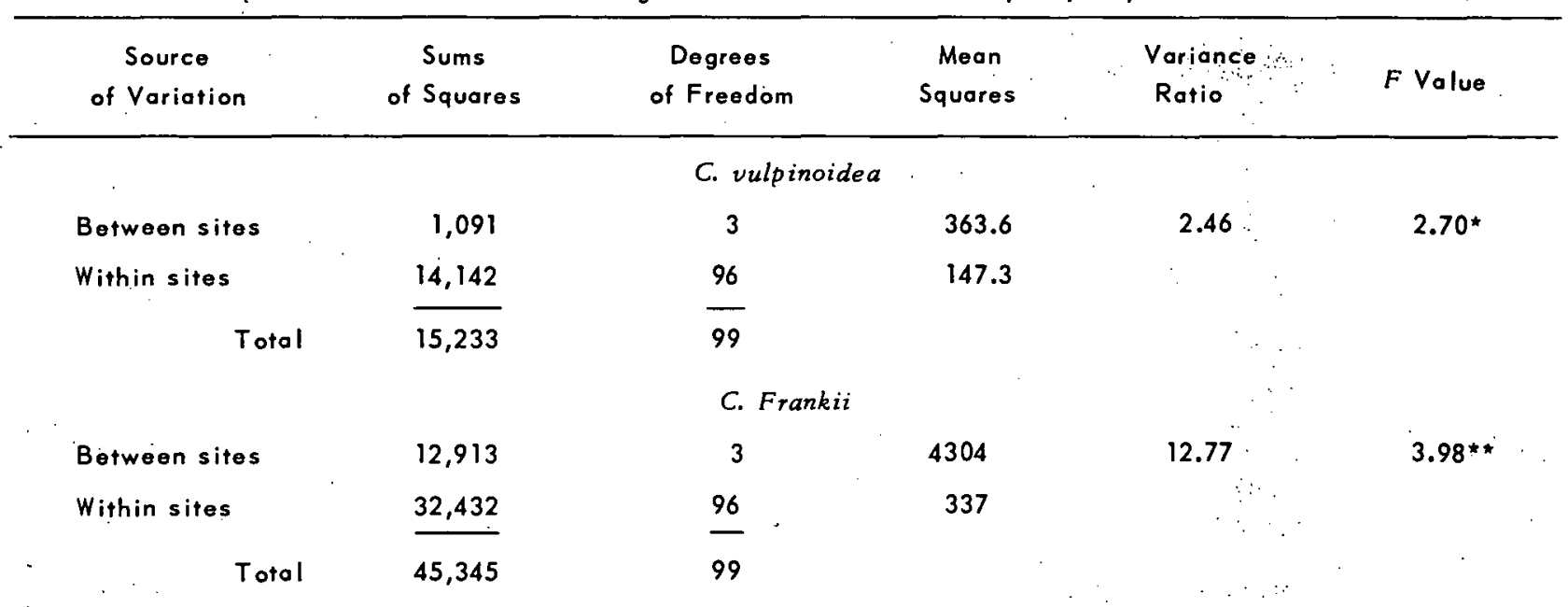

*Probability: 0.05 .

$\star \star$ Probability: 0.01 . 


$$
\begin{aligned}
s_{\bar{x}} & =\frac{\text { mean square within sites }}{a(a-1) / 2}=\frac{336.9}{4(3) / 2} \\
& =7.50333 .
\end{aligned}
$$

When $Q_{96.4}=3.7, D=27.8$; when $Q_{96,3}=3.376$, $D=25.3 ;$ when $Q_{96,2}=2.812, D=21.1$.

The $D$ values are compared with observed differences in the mean length of inflorescences according to sites in Table 4.

Of the six differences, two exceed their computed difference. These suggest that $C$. Frankii growing in the $20-\mathrm{mr} / \mathrm{hr}$ site have inflorescences significantly longer than members of the species growing in both the control and $10-\mathrm{mr} / \mathrm{hr}$ sites. The difference between the mean lengths on the 20 - and $40-\mathrm{mr} / \mathrm{hr}$ sites is not significant at the $5 \%$ probability level, but is significant at the $10 \%$ level. Similarly, the inflorescences produced on the $40-\mathrm{mr} / \mathrm{hr}$ site are probably longer than those produced on the $10-\mathrm{mr} / \mathrm{hr}$ as well as the control sites. It is also evident that the inflorescences from the $10-\mathrm{mr} / \mathrm{hr}$ area are very nearly the same leingth us those from the control areas.

The information in Tables 1 and 4 tentatively suggests that the mean length of the inflorescences of C. Frankii increases with the dose rate. In addition, the line of regression (Fig. 2) appears to confirm the suggestion that radiation has enhanced the growth of this species. However, certain other environmental factors are present

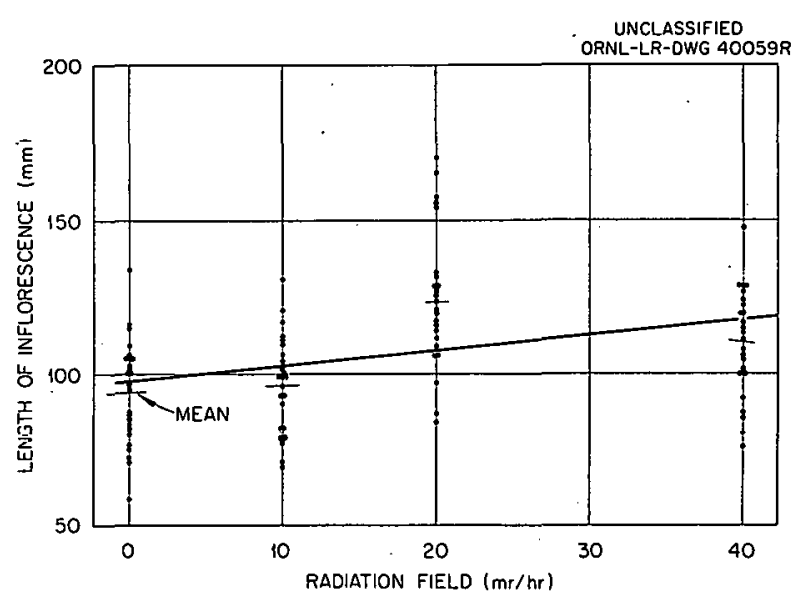

Fig. 2. Line of Regression Showing Relationship Between Lengths of Inflorescences and Dose Rate of the Radiation Field.

and the influences of these must be considered before this causal relationship can be affirmatively established.

\section{INTERACTION OF ENVIRONMENTAL FACTORS}

The size of a plant often varies with available water. The longest inflorescences of $C$. Frankii came from the wettest sites $(20 \mathrm{mr} / \mathrm{hr})$; the driest sites $(40 \mathrm{mr} / \mathrm{hr})$ produced the next longest; and the shortest grew on several sites (no radiation) where water relations appeared similar to

Table 4. Test for Comparison of Sample Means

C. Frankii - mean length of inflorescence according to radiation site

\begin{tabular}{ccccc}
\hline $\begin{array}{c}\text { Radiation Site } \\
(\mathrm{mr} / \mathrm{hr})\end{array}$ & $\begin{array}{c}\text { Sample Mean, } \\
\bar{x}(\mathrm{~mm})\end{array}$ & $\bar{x}-93.8$ & $\bar{x}-96.4$ & $\bar{x}-110.7$ \\
\hline 20 & 122.0 & 28.2 & 26.0 & 11.3 \\
& & $(27.8)$ & $(25.3)$ & $(21.1)$ \\
40 & 110.7 & 16.9 & 14.3 & $(21.1)$ \\
& & $(25.3)$ & & \\
10 & 96.4 & 2.6 &
\end{tabular}

* Means arranged from high to low; each subtracted from those above it. Observed differences are significant at 0.05 level if larger than the calculated $D$ value shown in parantheses. 
both of the above. On the other hand, C. vulpionidea produced the shortest inflorescences on the wettest sites $(20 \mathrm{mr} / \mathrm{hr})$ and the longest on the driest sites $(40 \mathrm{mr} / \mathrm{hr})$ as well as on sites without radiation.

Obviously, the two species have responded differently to the same kind of environmental factors. In the case of $C$. Frankii it might be assumed from the evidence that radiation had stimulated the production of longer flowering parts; however, more pistillate spikes were produced on the lake bed than on the control sites (Table 1). This kind of plant response is often associated with soil fertility. Apparently radiation has not enhanced the length of the inflorescences in C. vulpinoidea. Water relations, mineral nutrition, and soil alkalinity probably have interacted to produce the differences in growth response. The wettest sites are the most alkaline and the driest sites are the least al. kaline. A combination of both leaching and runoff could cause these differences between the sites.

The data suggest that $C$. Frankii will tolerate alkali soils ( $\mathrm{pH}$ 8) and will possibly respond favorably to these soil conditions whereas $C$. vulpinoidea is less tolerant.

The results indicate that these species of sedges respond differentially to the lake bed habitat. Carex Frankii develops long pistillate. spikes; whereas $C$ : vulpinoidea has comparatively. short inflorescences. Any effect of dose rate upon. this growth response' is: probably outweighed: by the influences of other environmental factors, particularly soil water, nutrients, and alkalinity. Thus, ionizing radiation alone in White Oak Lake bed during the past, few years produced no independently measurable effect upon the lengths of inflorescences of either C. Frankii or C. vulpinoidea.

\section{DISCUSSION}

Since ionizing radiation on White Oak Lake bed apparently has not influenced the size of the flower structures of the Carex species to an extent that is measurably independent of some. other environmental influences, it can be assumed that these plants posses some physiological tolerances to the dose rates involved. The nature of these tolerances may be due to a variety of factors and conditions:

1. The dose rate which will affect various activities in other plants extends over a wide range. Some species investigated at the Brookhaven radiation field have shown severe morphogenetic effects with dose rates of 30 to $50 \mathrm{r} /$ day. However, Gladiolus showed little or no effect from dose rates of 5000 to $6000 \mathrm{r} /$ day. ${ }^{12}$ As mentioned earlier, few plants show morphological changes at dose rates less than $15 . r / d a y$. Photosynthesis is only partially or temporarily inhibited by 100 to $500 \mathrm{kr} .{ }^{13}$ "Chromosome aberrations and mutations have been noted in significant numbers at dose rates below $1 \mathrm{r} /$ day. ${ }^{6}$ Thus, the dose rate anywhere on the lake bed is sufficient to induce genetical disturbances, but even the highest dose rate $(300 \mathrm{mr} / \mathrm{hr})$ is rather low compared with the dose rates used to induce physiological disturbances in very sensitive plants. The upper limit of the daily exposure will approximate 7 to $8 \mathrm{r}$ /day only in the most intensely radioactive patches. The typical dose rate over a wide portion of the area ranges between 500 and $1000 \mathrm{mr} /$ day.

2. Polycentric chromosomes, such as those found in: Carex species, ienhance the resistance of the plant to genetic disturbances which frequently accompany fragmentation of the chromosomes. The spindle attochments to the chromosome (or chromatids) are spread along the length, whereas a monocentric chromosome has but one spindle attachment. Fragmentation of a polycentric chromosome would produce. less serious., dis: turbances than would a. chromosome in: which half a chromatid and.all the genes for one characteristic move to the wrong: end. of the dividing cell.

3. The effects of ionizing radiation upon plants can be related also to the number and size of chromosomes present. 14 Plants with rather large chromosomes are somewhat radiosensitive. The size of the chromosomes in these Carex has not been compared with other species. On the other hand, polyploids, that is, plants with a multiple of the basic complement of chromosomes, are less sensitive than diploids within a species. The genus Carex probably has polyploid species

12A. H. Sparrow and J. E. Gunkel, Proc. Intern. Cont. Peaceful Uses Atomic Energy, Geneva, 1956 12, $52-59$ (1956).

${ }^{13}$ L. P. Zill and N. E. Tolbert, Arch. Biochem. Biopbys. 76, 196-203 (1958).

$14 \mathrm{~J}$. E. Gunckel and A. H. Sparrow, Brookbaven Symposia in Biol. No. 6, p 252-79 (1954). 
since the somatic numbers range from 12 to $112 .{ }^{15}$ The chromosome numbers of these species are not known.

Gray ${ }^{16}$ reports that biological disturbances have been observed when the rate of dissipation of energy along an ionizing tract reaches a value corresponding to the production of about 500 ions $/ \mu$. Since the lake bed soils contain 2 to $3 \mu \mathrm{c}$ of mixed radionuclides per $100 \mathrm{~g}$ of dry weight, it would seem, particularly when the soil is water-saturated, that disturbances could occur in this environment as well as within the plant parts that are underground.

4. Plants tend to show some recovery from radiation damage in ways not wholly dissimilar to the recovery habits of animals. Certain physiological adjustments for recovery and repair of irradiated protoplasm are well known.

It was pointed out earlier that these sedges were temporary residents in the lake bed habitat. If the processes of plant succession proceed normally, the sedges will be replaced by shrubs and eventually trees. At the present time both willows and sycamores are rapidly encroaching upon the communities, and have pioneers already established. Inasmuch as radiation on White Oak Lake bed can, and possibly does, disturb the genetical and physiological systems within these species, there are two levels at which any disturbance may become manifest, namely, within the organism and within the community. Manifestations of any organismal disturbance probably precede any manifestation of disturbance at the community level.

The data suggest that these species show no deleterious eiffects from the radiation present on

${ }^{15} \mathrm{C}$. D. Darlington and A. P. Wylie, Chromosome Atlas of Flowering Plants, 2d ed., George Allen and Unwin, London, 1955.

${ }^{16}$ L. H. Gray, Radiation Research 1, 89 (1954).
White Oak Lake bed. If, on the other hand, some disturbances have occurred, they have not been observed within these plants. Furthermore, the ecological (sociological) structure within the community is not expected to deviate from a typical pattern since these Carex species would normally give way to shrubs and trees.

\section{SUMMARY}

This study was conducted on the White Oak Lake bed where radionuclides are incorporated within the top soil in concentrations considerably more than might be expected from fallout. The lengths of pistillate flowering structures of two consorts, $C$. Frankii and C. vulpinoidea, were measured as growth response indicators of site quality with particular reference to the field of radiation in which they were growing, namely, $0,10,20$, and $40 \mathrm{mr} / \mathrm{hr}$.

Lengths varied with dose rate, but are believed to be independent of the ionizing radiation and more closely associated with other soil factors. Each sedge apparently responds' differently to the same soil moisture, fertility, and acidityalkalinity relationships. Carex Frankii is probably more tolerant to alkaline soils than is $C$. vulpinoidea.

lonizing radiation during the four growing seasons has not produced apparent aberrations in these plants. Even though biological disturbances have not been found, they can occur. The sojourn of these pioneering sedges in the lake bed habitat is likely to be so short that gross biological disturbances may not attain obvious magnitudes before these plants are replaced by succeeding forest species.

\section{ACKNOWLEDGMENT}

A note of appreciation is extended to $S$. I. Auerbach for making the facilities in the ecology laboratory available. 
THIS PAGE

\section{WAS INTENTIONALLY LEFT BLANK}


1. C. E. Center

2. Biology Library

3. Health Physics Library

4-5. Central Research Library

6. Reactor Experimental

Engineering Library

7-26. Laboratory Records Department

27. Laboratory Records, ORNL R.C.

28. L. B. Emlet (K-25)

29. J. P. Murray $(Y-12)$

30. A. M. Weinberg

31. E. D. Shipley

32. J. A. Swartout

33. K. Z. Morgan

34. C. P. Keim

35. M. L. Nelson

36. S. C. Lind

37. A. S. Householder

38. C. S. Harrill

39. C. E. Winters

40. A. H. Snell

41. E. H. Taylor

42. W. H. Jordan

43. T. A. Lincoln

44. A. Holloender

45. F. L. Culler

46. H. E. Seagren

47. D. Phillips

48. M. T. Kelley

49. E. E. Anderson

50. R. S. Livingston

51. R. A. Charpie

52. K. E. Cowser

53. C. D. Susano

54. L. B. Farabee

55. F. J. Davis

56. R. J. Morton

57. C. E. Haynes

58. H. F. Henry (K-25)

59. E. G. Struxness

60. W. E. Cohn

61. H. H. Hubbell, Jr.

62. D. E. Arthur

63. J. Neufeld

64. M. L. Randolph

65. P. M. Reyling

66. G. C. Williams
67. M. J. Skinner

68. J. C. Hart

69. T. H. J. Burnett

70. M. J. Cook

71. G. S. Hurst

72. T. E. Bortner

73. J. A. Lane

74. W. S. Snyder

75. D. R. Nelson

76. L. B. Holland

77. J. L. Gabbard

78. D. G. Jacobs

79. R. L. Bradshaw

80. A. C. Upton

81. D. M. Davis

82. P. E. Brown

83. E. D. Gupton

84. J. C. Ledbetter

85. R. L. Clark

86. G. C. Cain

87. L. C. Johnson

88. W. Ogg

89. O. D. Teague

90. E. L. Sharp

91. E. J. Kuna

92. H. H. Abee

93. C. R. Guinn

94. A. D. Warden

95. E. B. Wagrier

96-145. D. A. Crossley, Jr.

146. J. R. Muir

147. J. A. Auxier

148. M. F. Fair

149-198. S. I. Auerboch

199. G. W. Royster, Jr.

200. R. R. Dickison

201. J. D. McLendon

202. F. W. Sanders

203. F. C. Maienschein

204. W. J. Boegley, Jr.

205. F. L. Parker

206. B. R. Fish

207. M. B. Edwards

208. F. M. Empson

209. R. D. Birkhoff

210. R. H. Ritchie

211. J. A. Harter 
212. J. S. Cheka

213. P. N. Hensley

214. R. W. Peelle

215. P. B. Dunaway

216-265. J. S. Olson

266-315. D. J. Nelson

316. S. Wolff

317. Drew Schwartz

318. A. H. Haber

319. R. F. Kimball

320. J. S. Kirby-Smith

321. M. A. Kastenbaum
322. A. W. Kimball

323. W. L. Russell

324. R. S. Cockreham

325. J. C. Frye (consultant)

326. W. H. Langham (consultant)

327. R. L. Platzman (consultant)

328. L. S. . Taylor (consultant)

329. A. Wolman (consultant)

330. R. E. Zirkle (consultant)

331. ORNL - Y-12 Technical Library, Document Reference Section

\section{EXTERNAL DISTRIBUTION}

332-381. Gayther Plummer, Department of Botany, University of Georgia

382. Vincent Schultz, Environmental Sciences Branch, Division of Biology and Medicine, U.S. Atomic Energy Commission, Washington, D.C.

383. I. E. Wallen, Environmental Sciences Branch, Division of Biology and Medicine, U.S. Atomic Energy Commission, Washington, D.C.

384. H. F. Howden, Canada Department of Agriculture, Entomology Research Institute, Central Experimental Farm, Ottawa, Ontario, Canada

385. H. R. DeSelm, Department of Botany, University of Tennessee

386. W. D. Billings, Department of Botany, University of North Carolina

387. A. G. Norman, Department of Botany, University of Michigan

388. Wm. Benninghof, Department of Botany, University of Michigan

389. C. S. Shoup, Division of Research and Development, AEC, ORO

390-409. Oak Ridge Institute of Nuclear Studies, University Relations Division

410. C. P. Straub, Public Health Service, Robert A. Taft Sanitary Engineering Center

411. Division of Research and Development, AEC, ORO

412. John Wolfe, Division of Biology and Medicine, U.S. Atomic Energy Commission, Washington, D.C.

413. Orlando Park, Department of Biology, Northwestern University, Evanston, Illinois

414. Eugene Odum, Department of Zoology, University of Georgia, Athens

415. J. J. Davis, Biology Operation, Hanford Atomic Products Operations, Seattle, Washington

416. Royal Shanks, Department of Botany, University of Tennessee

417. Robert B. Platt, Department of Biology, Emory University, Georgia

418. H. P. Yockey, Aerojet-General Nucleonics, San Ramon, California

419-988. Given distribution as shown in TID-4500 (15th ed.) under Biology and Medicine category

(75 copies - OTS) 